SE and range and analysis of variance. The level of significance was set at 0.05 . The findings of the study in relation to will to win showed insignificant difference among short distance runners, long distance runners, jumpers and throwers. On the basis of the findings of the study, the following conclusions are drawn: insignificant difference among short distance runners, long distance runners, jumpers and throwers was found as will to win is defined as the intensity of the desire to defeat an opponent or to exceed some performance standard in a given sports.

\section{WILL TO WIN AS A PSYCHOLOGICAL DIFFERENTIAL TO PLAY AND TRIUMPH AMONG FEMALE RUNNERS, JUMPERS AND THROWERS}

T Onima Reddy, ${ }^{1}$ Vikram Singh, 1 T Pushpa Reddy ${ }^{2}$ 'Department of Physical Education, Banaras Hindu University, Varanasi, Uttar Pradesh, India; ${ }^{2}$ LNUPE, Gwalior, Madhya Pradesh, India

10.1136/bjsm.2010.078725.184

The purpose of the study was to compare will to win as a psychological differential to play and triumph among female runners, jumpers and throwers. For the purpose of the study, 60 female athletes (15 short distance runners, 15 long distance runners, 15 jumpers and 15 throwers) were randomly selected from 10th National Junior Federation Cup Athletic Championship 2010 held at Visakhapatnam as the subjects of the study. The variable selected for the purpose of this study was: will to win. Will to win was assessed by the total scores in Will to Win Questionnaire constructed and standardised by Prof Anand Kumar Shrivastava and Prem Shankar Shukla. With the help of the questionnaire related to will to win as a psychological variable necessary data were collected. Data were collected with regard to will to win variable from 60 female athletes in 10th National Junior Federation Cup Athletic Championship 2010 held at Visakhapatnam. The data was analysed by applying descriptive statistic that is, mean, SD, 